\title{
Article \\ Effect of a Geothermal Heat Pump in Cooling Mode on the Housing Environment and Swine Productivity Traits
}

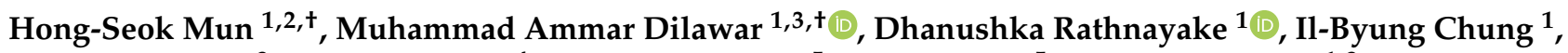 \\ Chong-Dae Kim ${ }^{3}$, Sang-Bum Ryu ${ }^{4}$, Kwang-Woo Park ${ }^{5}$, Sang-Ro Lee ${ }^{5}$ and Chul-Ju Yang 1,3,* \\ 1 Animal Nutrition and Feed Science Laboratory, Department of Animal Science and Technology, Sunchon \\ National University, Suncheon 57922, Korea; mhs88828@nate.com (H.-S.M.); \\ ammar_dilawar@yahoo.com (M.A.D.); dhanus871@gmail.com (D.R.); ilbyungchung@daum.net (I.-B.C.) \\ 2 Department of Multimedia Engineering, Sunchon National University, Suncheon 57922, Korea \\ 3 Interdisciplinary Program in IT-Bio Convergence System (BK21 plus), Sunchon National University, 255, \\ Jungangno, Suncheon 57922, Korea; chongkim429@gmail.com \\ 4 Department of Mechanical Convergence Engineering, Hanyang University, Seoul 04763, Korea; \\ fbvod@hanmail.net \\ 5 WP Co., Ltd., Suncheon 58023, Korea; pkw9872@naver.com (K.-W.P.); skylife37@naver.com (S.-R.L.) \\ * Correspondence: yangcj@sunchon.ac.kr; Tel.: +82-61-750-3235 \\ + Both authors have contributed equally to the manuscript as co-first authors.
}

check for

updates

Citation: Mun, H.-S.; Dilawar, M.A.; Rathnayake, D.; Chung, I.-B.; Kim, C.-D.; Ryu, S.-B.; Park, K.-W.; Lee,

S.-R.; Yang, C.-J. Effect of a

Geothermal Heat Pump in Cooling Mode on the Housing Environment and Swine Productivity Traits. Appl. Sci. 2021, 11, 10778. https://doi.org/ 10.3390/app112210778

Academic Editor: Ben J. Anthony

Received: 15 October 2021

Accepted: 11 November 2021

Published: 15 November 2021

Publisher's Note: MDPI stays neutral with regard to jurisdictional claims in published maps and institutional affiliations.

Copyright: (C) 2021 by the authors. Licensee MDPI, Basel, Switzerland. This article is an open access article distributed under the terms and conditions of the Creative Commons Attribution (CC BY) license (https:// creativecommons.org/licenses/by/ $4.0 /)$.

\begin{abstract}
This study compared the effects of the cooling mode of a geothermal heat pump (GHP) system with those of a traditional cooling system (ventilation fans) inside a pig house on the internal house temperature, harmful gas emissions, and the growth performance of the pigs. During the 19-week experimental period, the temperature inside the house connected to the GHP cooling system was significantly lower $(p<0.05)$ than that of a house with a conventional cooling system. Similarly, the temperature-humidity index (THI) was significantly reduced $(p<0.05)$ in the GHP cooling system-connected pig house. Furthermore, the concentrations of ammonia $\left(\mathrm{NH}_{3}\right)$ and hydrogen sulfide $\left(\mathrm{H}_{2} \mathrm{~S}\right)$ were also decreased significantly in the GHP-installed pig house $(p<0.05)$. However, no differences were observed in the concentrations of particulate matter $\left(\mathrm{PM}_{2.5}\right)$ and formaldehyde $(p>0.05)$. The pigs reared in the GHP-equipped pig house gained significantly more weight $(p<0.05)$ by the end of the experiment. The GHP cooling system can therefore be implemented as a renewable, environmentally friendly energy source in pig farms for sustainable swine production without adversely affecting the productivity parameters.
\end{abstract}

Keywords: geothermal heat pump; ammonia; temperature-humidity index; renewable energy source; pigs

\section{Introduction}

Energy, as a topic, is gaining attention in the livestock sector because the consumption of energy in the rearing of animals will play a vital role in the future. According to UN research [1], the world population will reach 9.15 billion by 2050, thus increasing the demand for food. This will lead to an increase in the consumption of livestock products by $40-80 \%$, compared with the consumption in 2010 [2]. As a result, the energy required to sustain the demand for animal protein will increase in the near future. Against the background of decreasing fossil energy resources due to their high demand and price, the use of renewable energy resources is an important alternative to energy from fossil fuels in the agriculture sector [3].

The use of energy in livestock production has gained attention recently because of its harmful impact on the environment [4]. In pig housing, it is necessary to provide an adequate housing environment for optimum production, and to satisfy the legislation regarding animal welfare demands [5]. Temperature, moisture, and indoor air quality are important parameters for indoor housing environments. Temperature control is crucial for 
pigs, and a slight variation in the inside temperature has a negative impact on their health, growth, and performance [6]. A pig house contains a large variety of air pollutants-such as $\mathrm{NH}_{3}, \mathrm{CO}_{2}$, fine particles, microbes, and endotoxins-which cause environmental pollution and global warming [7]. Therefore, it is time to utilize renewable energy resources which reduce environmental pollution for the maintenance of indoor housing environments.

GHP systems have been successfully utilized as alternative renewable energy sources [8] in many countries [9]. They are environmentally friendly, and can reduce electricity consumption [10]. In a GHP system, the internal air quality improves owing to the supply of fresh air, and there is also no direct combustion that produces pollutants [11]. Similarly, GHP can reduce electricity consumption by consuming one unit of electricity to provide three units of geothermal energy [12]. The use of renewable energy sources is relatively low in Korea compared to other developed countries; however, GHP systems have been gaining popularity for cooling and heating. The Korean government is taking steps to increase the use of new and renewable energy from $2.1 \%$ in 2004 to $11 \%$ in 2030. In Korea, the energy acquired will be 200 times the main energy consumption if $2 \%$ of the geothermal energy resources to a depth of $5 \mathrm{~km}$ are used [13]. These energy resources can be used at a depth of 100-500 $\mathrm{m}$ to operate a GHP for livestock [14]. Several authors $[4,7,14,15]$ have reported the beneficial effects of a heating system using a GHP on environmental pollution, energy consumption, and production performance in livestock farms. However, to the best of our knowledge, the cooling effects of GHP systems in pig farms during summer have not yet been reported. Therefore, the aim of this experiment was to assess the effects of the GHP cooling system on pig growth performance, housing conditions, and the emission of noxious gases.

\section{Materials and Methods}

\subsection{Ethics}

This study was performed at the experimental farm of Sunchon National University, 57922 Suncheon, South Korea. All of the experimental protocols and the rearing of the animals were in line with the guidelines of the Animal Care and Use Committee (SCNU IACUC 2020-09).

\subsection{Experimental Design}

The performance of the GHP cooling mode was evaluated in a pig house during the summer season. The pigs were reared for 19 weeks, from 29 May 2020 to 9 October 2020. The growth period was further divided into four phases, as follows: 5 weeks for weaning, 4 weeks for growing, 5 weeks for early finishing, and 5 weeks for the late finishing phase. The pig house was divided into two separate rooms ( $3 \mathrm{~m}$ wide $\times 8 \mathrm{~m}$ long), which were further divided into 10 individual pens for replication (Figure 1).

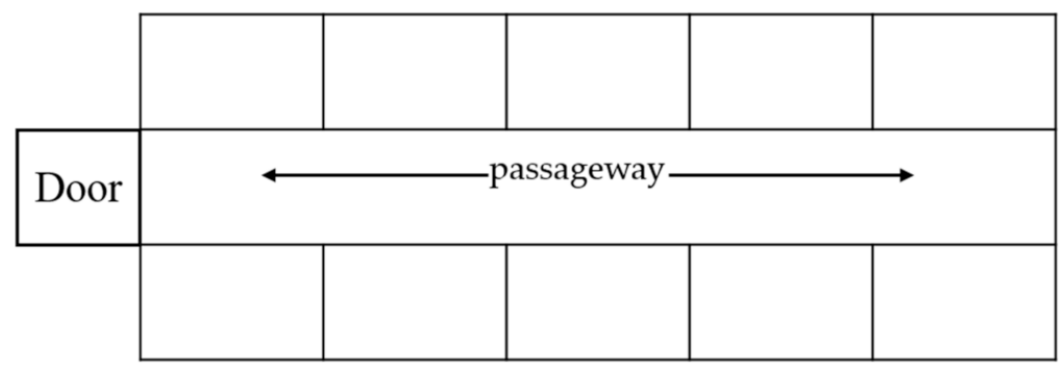

Figure 1. Schematic view of the experimental pig house.

Both rooms were environmentally controlled and were orientated similarly; the first was installed with a conventional cooling system (ventilation fans) and served as a control, while the other room was connected to the ground water source geothermal heat pump in cooling mode. The control pig house was equipped with one big fan and two small fans operating at 1150 and $1700 \mathrm{rpm}$, respectively. The ventilatory volume of the large 
fan ranged from 677 cubic feet per minute (CFM) to 1574 CFM, while that of the small fan ranged from 451 to 1097 CFM. The ventilation rate was regulated at $75 \mathrm{CFM} /$ unit for the early and late finishing pigs, 35 CFM/unit for growing pigs, and $25 \mathrm{CFM} / \mathrm{unit}$ for weaning piglets. The pigs were reared on slatted floors, and were offered water and commercially available phase-appropriate feed ad libitum. The feed formulation and chemical composition of the diets are presented in Table 1.

Table 1. Diet formulae and chemical composition of the experimental diets.

\begin{tabular}{|c|c|c|c|}
\hline & $\begin{array}{c}\text { Weaning Pigs } \\
0-5 \text { Weeks }\end{array}$ & $\begin{array}{l}\text { Growing Pigs } \\
\text { 5-9 Weeks }\end{array}$ & $\begin{array}{c}\text { Finishing Pigs } \\
\text { 10-19 Weeks }\end{array}$ \\
\hline \multicolumn{4}{|c|}{ Ingredients (\% as fed basis) } \\
\hline Yellow corn & 47.85 & 51.34 & 54.00 \\
\hline Rice bran & 14.00 & 7.00 & 9.00 \\
\hline Rapeseed oil & 0.00 & 1.72 & 3.00 \\
\hline DDGS & 0.00 & 6.00 & 6.00 \\
\hline Soybean meal & 22.10 & 21.80 & 18.00 \\
\hline Limestone & 0.70 & 0.86 & 1.00 \\
\hline Calcium Phosphate & 0.70 & 0.10 & 0.20 \\
\hline Salt & 0.15 & 0.30 & 0.30 \\
\hline Vit-min premix ${ }^{1}$ & 0.50 & 0.45 & 0.20 \\
\hline Animal fat & 7.00 & 6.78 & 4.86 \\
\hline Molasses & 2.00 & 2.50 & 2.50 \\
\hline Amino Acid additive & 5.00 & 1.15 & 0.94 \\
\hline \multicolumn{4}{|c|}{ Analyzed composition (g/kg dry matter) } \\
\hline Dry matter & 879 & 876 & 881 \\
\hline Crude protein & 190 & 180 & 170 \\
\hline Crude fat & 43 & 44 & 44 \\
\hline Crude fiber & 39 & 38 & 38 \\
\hline $\mathrm{Ca}$ & 7.0 & 8.0 & 8.0 \\
\hline Available P & 4.4 & 3.4 & 3.4 \\
\hline Lysine & 10.35 & 10.20 & 10.10 \\
\hline Methionine & 5.3 & 3.7 & 3.1 \\
\hline
\end{tabular}

${ }^{1}$ Vit-min premix contained following nutrients/kg: vitamin $\mathrm{D}_{3}, 800 \mathrm{IU}$; vitamin $\mathrm{A}, 6000 \mathrm{IU}$; vitamin $\mathrm{K}_{3}, 2 \mathrm{mg}$ vitamin E, $20 \mathrm{IU}$; thiamin, $2 \mathrm{mg}$; riboflavin, $4 \mathrm{mg}$; vitamin $\mathrm{B}_{12}, 1 \mathrm{mg}$; niacin, $10 \mathrm{mg}$; pantothenic acid, $11 \mathrm{mg}$; biotin, $0.02 \mathrm{mg}$; vitamin $\mathrm{B}_{6}, 20 \mathrm{IU}$; manganese, $90 \mathrm{mg}$; copper, $21 \mathrm{mg}$; iron (ferrous), $100 \mathrm{mg}$; zinc, $60 \mathrm{mg}$; iodine, $1.0 \mathrm{mg}$; cobalt, $0.3 \mathrm{mg}$; selenium, $0.3 \mathrm{mg}$.

\subsection{Description of the GHP System}

The heat pump unit (DHGW 5N-C4-02, Daesung Heat Enersys, Seoul, Korea) was installed in the pig house (Figures 2 and 3). The system consisted of a $150 \mathrm{~m}$-deep double U-tube borehole exchanger (BHE), a fan coil unit (FCU), water-circulating pumps, and a water tank. The cooling ability of the heat pump was $20.59 \mathrm{~kW}$, with a $4.93 \mathrm{~kW}$ rating of electric power consumption. The freezing capacity of the system was $2.1 \mathrm{RT}$, and R-410A was used as a refrigerant. The water storage capacity of the tank was approximately $260 \mathrm{~L}$. The FCU can generate different wind speeds, with a temperature range of $5-45^{\circ} \mathrm{C}$. Three circulating pumps (Wilo Pump, Ansan, Korea) were attached to the system: (1) a PH-200M with a flow rate of $136 \mathrm{~L} / \mathrm{min}$, which was used for the transfer of ground water to the heat pump; (2) a PH-080M with a flow rate of $75 \mathrm{~L} / \mathrm{min}$, which was used for the transfer of water from the heat pump to the tank; and (3) a PB-600MA with a flow rate of $80 \mathrm{~L} / \mathrm{min}$, which was used for the transfer of water from the tank to the pig house.

The heat pump unit had a rolling compressor piston, a thermostatic expansion valve, and a copper tube with tube heat exchangers. The exchangers increased (in heating mode) and decreased (in cooling mode) the temperature of air, and distributed it through the pig house via plastic ducts. The air inside the pig house was replaced with incoming air. The volumetric flow of air through the heat pump was $700 \mathrm{~m}^{3} / \mathrm{min}$. 


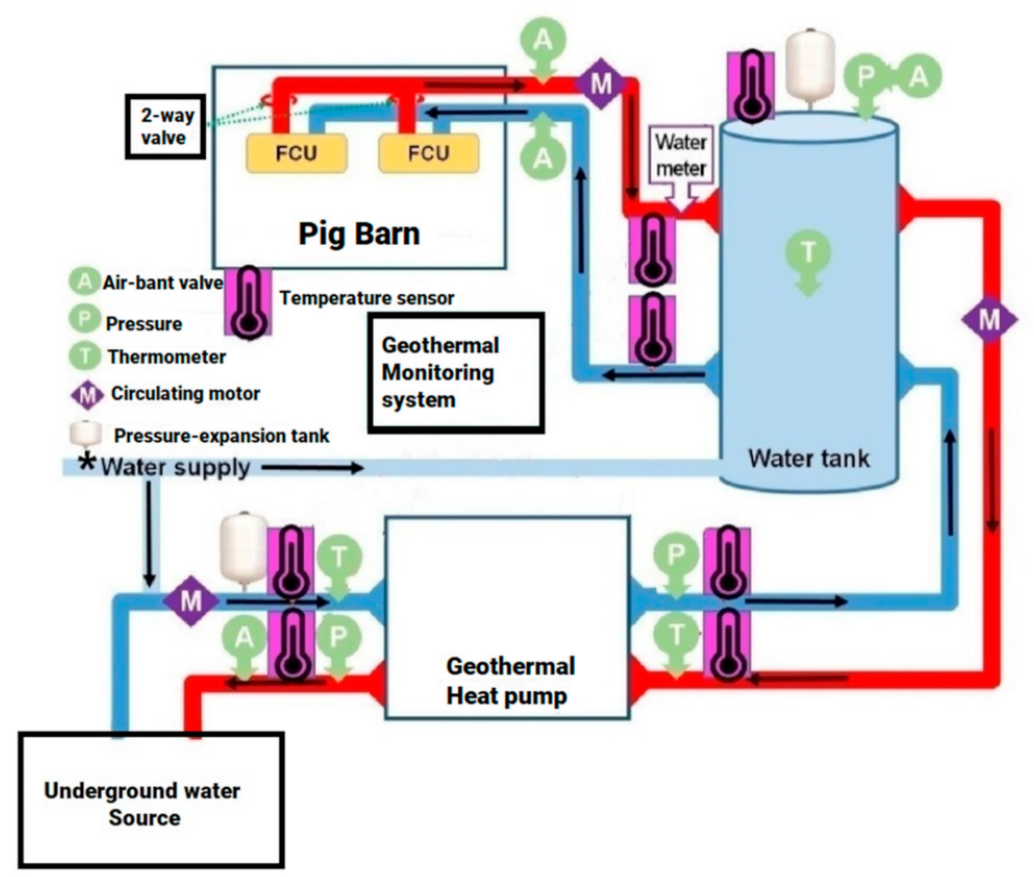

Figure 2. Schematic view of the geothermal heat pump and geothermal monitoring system. The red coloured pipes show hot water and the blue colour shows cold water. * Emergency water supply.

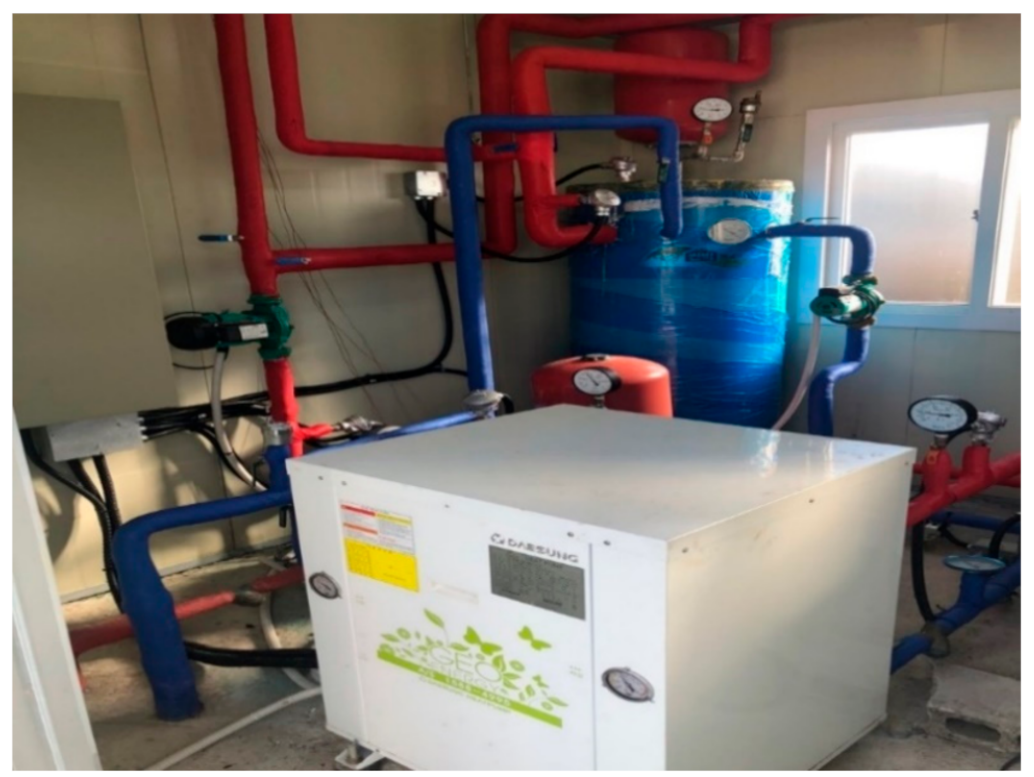

Figure 3. GHP system with a water tank and pipes installed at the pig farm.

\subsection{Internal House Temperature and Temperature-Humidity Index (THI)}

The temperature and humidity were measured using T-type thermocouples and thermistors with sensors with a range of -20 to $80{ }^{\circ} \mathrm{C} \pm 0.2{ }^{\circ} \mathrm{C}$ for temperature and $0-100 \%$ for humidity.

The temperature-humidity index (THI) was calculated from the relative humidity and temperature as an indicator of the heat stress using the following equation [16]:

$$
\mathrm{THI}=0.8 \mathrm{~T}+(\mathrm{RH} / 100) \times(\mathrm{T}-14.3)+46.4,
$$

where $\mathrm{T}=$ temperature $\left({ }^{\circ} \mathrm{C}\right)$, and $\mathrm{RH}=$ relative humidity $(\%)$. 


\subsection{Coefficient of Performance (COP) and the Heat Pump Outflow and Inflow Temperatures}

The temperature of the inflow and outflow water (hot and cold) of the GHP was measured using a GPT-1000 pipe temperature sensor (Ginice, Korea), which is equipped with a high-grade thermistor sensing element with a temperature ranging from $-50^{\circ} \mathrm{C}$ to $150{ }^{\circ} \mathrm{C}$.

The COP of the system in cooling mode was calculated using equation [9]:

$$
\begin{gathered}
\mathrm{COP}=\frac{\text { Cooling capacity }}{\text { Power input }} \\
\mathrm{COP}=\frac{\mathrm{QH}-\mathrm{W}}{\mathrm{W}}
\end{gathered}
$$

where $\mathrm{QH}=$ heat transferred to the ground $(\mathrm{kW})$, and $\mathrm{W}=$ total electricity consumption $(\mathrm{kWh})$

\subsection{Concentration of Ammonia $\left(\mathrm{NH}_{3}\right)$ and Hydrogen Sulfide $\left(\mathrm{H}_{2} \mathrm{~S}\right)$}

The concentration of $\mathrm{NH}_{3}$ was measured by installing a sensor (City Technology $\mathrm{NH}_{3}$ 3E 100 SE, Bonn, Germany) at a height of $1.9 \mathrm{~m}$ in the middle of the swine house, with a range of 0-50 ppm. Similarly, the concentration of $\mathrm{H}_{2} \mathrm{~S}$ was measured by installing a sensor (Alphasense Ltd. $\mathrm{H}_{2} \mathrm{~S}-\mathrm{B} 4$ sensor, Great Notley, UK). Every week, the concentrations of both gases were also measured manually using a gas sampling pump (Gastec Corp, GV-100, Ayase-Shi, Japan) and gas detection tubes ( $3 \mathrm{~L}$ for $\mathrm{NH}_{3}$ and $4 \mathrm{LT}$ for $\mathrm{H}_{2} \mathrm{~S}$ ) to validate the values from the sensors.

\subsection{Formaldehyde (FA) and Particulate Matter $\left(P M_{2.5}\right)$}

The FA and $\mathrm{PM}_{2.5}$ levels were measured daily by placing a sensor (Smart Air quality meter AR830A, Dongguan, China) in the middle of the pig house. The range of the sensor was $0-150 \mu \mathrm{g} / \mathrm{m}^{3}$ for $\mathrm{PM}_{2.5}$ and 0-50 ppm for formaldehyde.

\subsection{Growth Performance Measurement}

The body weight gain (BWG), feed intake (FI), and feed conversion ratio (FCR) were measured. The animals were weighed at the start and end of each phase individually (weaning, growing, finishing, and late-finishing), and the BWG was calculated weekly. The FI was determined weekly by subtracting the remaining feed from the total amount of feed offered. The FCR was calculated by dividing the FI by the BWG.

\subsection{Statistics}

Statistical Analysis System software (SAS 2011, Cary, NS, USA) was used to analyze the data, and the results are shown as the mean values and the standard error of the mean (SEM). The analysis of variance (ANOVA) was used to compare the parameters in the groups, and Duncan's multiple range test was used to compare the means. Tendencies were identified when $0.05<p<0.10$, and differences were considered significant at $p<0.05$.

\section{Results}

\subsection{Pig House Temperature and THI}

The inside temperatures of the control and GHP cooling system houses are presented in Table 2. The setting temperature during the weaning phase was maintained at $26^{\circ} \mathrm{C}$, and was then gradually reduced at a rate of $1{ }^{\circ} \mathrm{C}$ every week until it reached $20^{\circ} \mathrm{C}$. The temperature during the weaning and growing phases did not decrease $(p>0.05)$. However, the inside temperature was reduced $(p<0.05)$ in the early and late finishing periods. The temperature during early finishing and late finishing was decreased by $17 \%$ and $9 \%$, respectively, in the GHP cooling system relative to the temperature of the control house. Similarly, the THI of the GHP-installed pig house was decreased $(p<0.05)$ over the 19-week trial (Figure 4). 
Table 2. Effect of the GHP cooling mode on the inside temperature of the pig house.

\begin{tabular}{cccccc}
\hline Items & Outside & Control & GHP & SEM & $p$-Value \\
\hline Weaning & 28.70 & 25.85 & 25.32 & 0.21 & 0.0495 \\
Growing & 27.31 & 24.31 & 23.85 & 0.21 & 0.2134 \\
Early Finishing & 31.12 & $27.76^{\mathrm{a}}$ & $22.93^{\mathrm{b}}$ & 0.15 & $<0.0001$ \\
Late Finishing & 26.49 & $22.20^{\mathrm{a}}$ & $20.28^{\mathrm{b}}$ & 0.17 & $<0.0001$ \\
Average & 28.40 & $25.07^{\mathrm{a}}$ & $23.84^{\mathrm{b}}$ & 0.22 & $<0.0001$ \\
\hline
\end{tabular}

$\mathrm{a}, \mathrm{b}$ Values within the same row with different letters differ significantly.

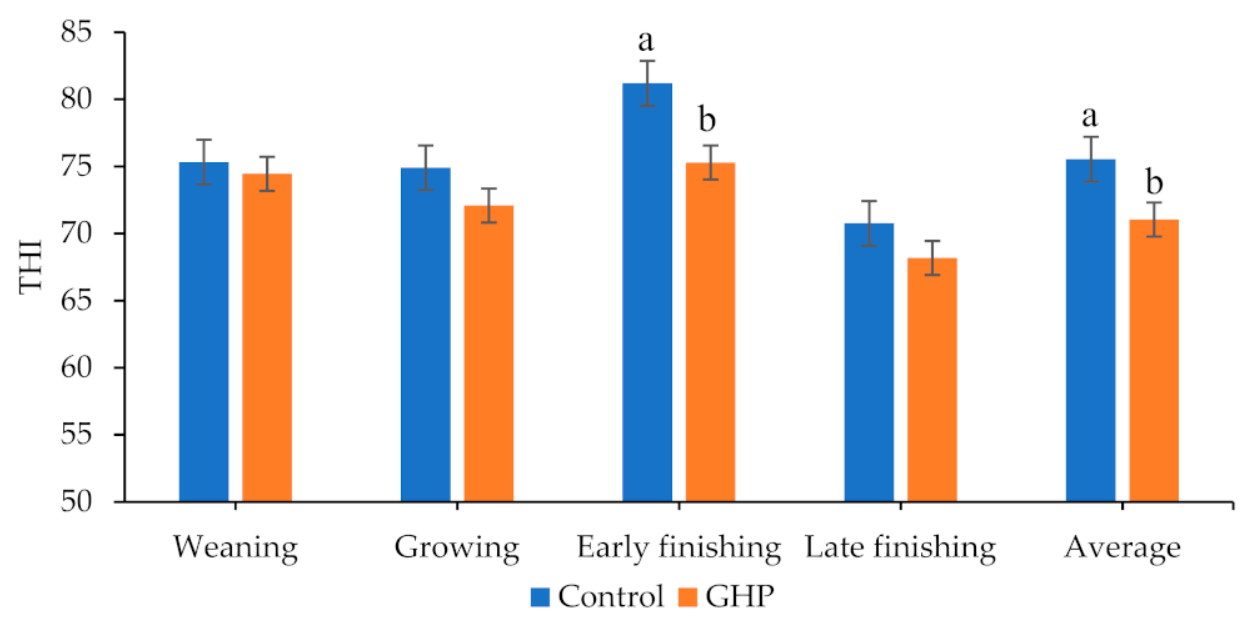

Figure 4. Effect of the GHP cooling mode on the temperature-humidity index (THI). The data are presented as the mean \pm SEM. ${ }^{a, b}$ Values with different superscripts within the same bars differ significantly $(p<0.05)$.

\subsection{Heat Pump Outlet and Inlet Temperature and COP}

The outflow water temperature from the heat pump decreased by 7.44, 14.74, and $11.83^{\circ} \mathrm{C}$ during the weaning, growing, and finishing phases, respectively, compared to the inflow water temperature. The maximum and minimum COP calculated were 4.50 during the early finishing and 4.10 during the weaning phase, respectively (Table 3 ).

Table 3. Heat pump water flow temperature and the coefficient of performance (COP) of the GHP cooling mode.

\begin{tabular}{|c|c|c|c|c|c|}
\hline \multirow[t]{2}{*}{ Periods } & \multicolumn{2}{|c|}{$\begin{array}{c}\text { Heat Pump Water Flow } \\
\text { Temperature }\left({ }^{\circ} \mathrm{C}\right)\end{array}$} & \multirow[t]{2}{*}{ Difference } & \multirow{2}{*}{$\begin{array}{l}\text { Heat Pump } \\
\text { Consumption } \\
(\mathbf{k W h})\end{array}$} & \multirow[t]{2}{*}{ COP } \\
\hline & Outflow & Inflow & & & \\
\hline Weaning & 26.11 & 33.55 & 7.44 & 44.80 & 4.10 \\
\hline Growing & 20.22 & 34.96 & 14.74 & 44.20 & 4.46 \\
\hline Early Finishing & 19.92 & 31.75 & 11.83 & 48.20 & 4.50 \\
\hline Late Finishing & 20.16 & 29.30 & 9.14 & 44.60 & 4.40 \\
\hline Average & 21.60 & 32.39 & 10.79 & 45.45 & 4.36 \\
\hline
\end{tabular}

\subsection{Particulate Matter $\left(\mathrm{PM}_{2.5}\right)$, Formaldehyde, $\mathrm{NH}_{3}$ and $\mathrm{H}_{2} \mathrm{~S}$ Concentartions}

The concentration of FA in the pig house was not affected $(p>0.05)$ by the cooling system during the experiment (Table 4). Similarly, the concentration of $\mathrm{PM}_{2.5}$ remained unaffected $(p>0.05)$, except during the early finishing phase. On the other hand, the concentration of noxious gases $\left(\mathrm{NH}_{3}\right.$ and $\left.\mathrm{H}_{2} \mathrm{~S}\right)$ decreased $(p<0.05)$ in the GHP-connected pig house compared to the control (Figure 5). 
Table 4. Effect of the GHP cooling mode on the formaldehyde (ppm), $\mathrm{PM}_{2.5}\left(\mu \mathrm{g} / \mathrm{m}^{3}\right)$ and hydrogen sulfide $\left(\mathrm{H}_{2} \mathrm{~S}\right)(\mathrm{ppb})$ in the pig house.

\begin{tabular}{ccccc}
\hline Items & Control & GHP & SEM & $p$-Value \\
\hline & \multicolumn{2}{c}{ Particulate matter $\left(\mathrm{PM}_{2.5} \mu \mathrm{g} / \mathrm{m}^{3}\right)$} & 2.44 & 0.8610 \\
Weaning & 22.51 & 21.86 & 2.39 & 0.7932 \\
Growing & 16.25 & 15.32 & 4.90 & 0.7514 \\
Early Finishing & 34.17 & 31.97 & 3.67 & 0.9223 \\
Late finishing & 25.49 & 24.94 & 1.90 & 0.7163 \\
Average & 25.05 & 24.07 & & 0.0611 \\
& & Formaldehyde (ppm) & 0.01 & 0.2638 \\
Weaning & 0.07 & 0.10 & 0.01 & 0.0431 \\
Growing & 0.08 & 0.10 & 0.02 & 0.0595 \\
Early Finishing & $0.11^{\mathrm{a}}$ & $0.05^{\mathrm{b}}$ & 0.01 & 0.5051 \\
Late Finishing & 0.08 & 0.13 & 0.01 & 0.0002 \\
Average & 0.09 & 0.09 & 0.01 & 0.0325 \\
Weaning & $13.00^{\mathrm{a}}$ & $0.14^{\mathrm{b}}$ & 0.02 & 0.0199 \\
Growing & $7.00^{\mathrm{a}}$ & $0.03^{\mathrm{b}}$ & 0.01 & 0.0011 \\
Early Finishing & $5.00^{\mathrm{a}}$ & $1.28^{\mathrm{b}}$ & 0.10 & \\
Late Finishing & $16.00^{\mathrm{a}}$ & $0.21^{\mathrm{b}}$ & 0.01 & \\
Average & $10.00^{\mathrm{a}}$ & $0.44^{\mathrm{b}}$ &
\end{tabular}

$\overline{\mathrm{a}, \mathrm{b}}$ Values within the same row with different letters differ significantly.

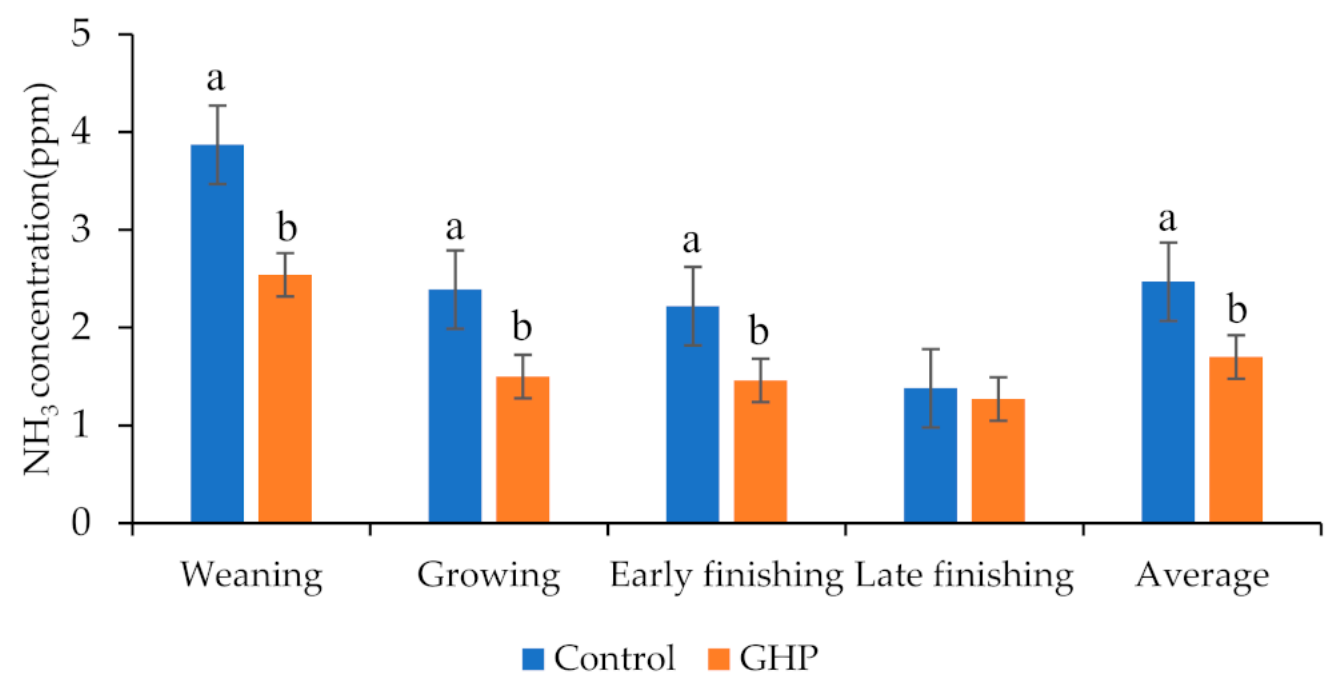

Figure 5. Effect of the GHP cooling mode on the ammonia $\left(\mathrm{NH}_{3}\right)$ concentration. The data are presented as the mean \pm SEM. ${ }^{a, b}$ Values with different superscripts within the same bars differ significantly $(p<0.05)$.

\subsection{Growth Performance}

Table 5 shows the effect of the GHP cooling system on the growth performance of the pigs. From 0 to 19 weeks, the weight of pigs significantly increased in the GHP-connected house relative to that in the control $(p<0.05)$. 
Table 5. Effect of the GHP cooling mode on the growth performance parameters.

\begin{tabular}{|c|c|c|c|c|}
\hline Parameter & Control & GHP & SEM & $p$ Value \\
\hline \multicolumn{5}{|c|}{$0-5$ weeks } \\
\hline Initial body weight $(\mathrm{kg})$ & 6.18 & 6.17 & 0.37 & 0.9910 \\
\hline Final body weight (kg) & 23.74 & 25.84 & 0.88 & 0.1250 \\
\hline Weight gain $(\mathrm{kg})$ & 17.56 & 19.67 & 0.77 & 0.0850 \\
\hline Feed intake (kg) & $26.60^{b}$ & $31.10^{\mathrm{a}}$ & 1.26 & 0.0350 \\
\hline Feed conversion ratio & 1.52 & 1.59 & 0.06 & 0.4390 \\
\hline \multicolumn{5}{|c|}{ 6-9 weeks } \\
\hline Final body weight (kg) & 48.53 & 51.35 & 1.66 & 0.2490 \\
\hline Weight gain (kg) & 24.79 & 25.51 & 0.91 & 0.7250 \\
\hline Feed intake (kg) & $51.83^{b}$ & $52.71^{\mathrm{a}}$ & 2.21 & 0.0005 \\
\hline Feed conversion ratio & 2.11 & 2.07 & 0.05 & 0.6700 \\
\hline \multicolumn{5}{|c|}{ 10-14 weeks } \\
\hline Final body weight (kg) & $75.61^{b}$ & $82.58^{a}$ & 1.88 & 0.0220 \\
\hline Weight gain (kg) & 27.09 & 31.23 & 1.01 & 0.0840 \\
\hline Feed intake $(\mathrm{kg})$ & $81.29^{b}$ & $91.62^{\mathrm{a}}$ & 2.42 & 0.0140 \\
\hline Feed conversion ratio & 3.03 & 2.94 & 0.14 & 0.8210 \\
\hline \multicolumn{5}{|c|}{ 15-19 weeks } \\
\hline Final body weight (kg) & $108.47^{b}$ & $118.17^{a}$ & 2.56 & 0.0240 \\
\hline Weight gain $(\mathrm{kg})$ & 32.86 & 35.58 & 0.82 & 0.2760 \\
\hline Feed intake $(\mathrm{kg})$ & $101.16^{b}$ & $120.53^{a}$ & 2.76 & 0.0008 \\
\hline Feed conversion ratio & $3.10^{b}$ & $3.39^{\mathrm{a}}$ & 0.13 & 0.0280 \\
\hline \multicolumn{5}{|c|}{ 0-19 weeks } \\
\hline Final body weight (kg) & $108.47^{\mathrm{b}}$ & $118.17^{\mathrm{a}}$ & 2.56 & 0.0240 \\
\hline Weight gain (kg) & $102.29^{b}$ & $111.99^{\mathrm{a}}$ & 2.47 & 0.0170 \\
\hline Feed intake (kg) & 260.88 & 295.96 & 6.96 & 0.0780 \\
\hline Feed conversion ratio & 2.56 & 2.64 & 0.05 & 0.4390 \\
\hline
\end{tabular}

a,b Values within the same row with different letters differ significantly.

\section{Discussion}

The ambient temperature inside a pig house is a crucial parameter for pig farming, and variation in this parameter may have a negative impact on pig productivity [17]. In Korea, heating pig houses is essential during the winter season, whereas they need to be cooled in hot weather. Research has shown that heat shock or cold stress substantially affect the growth and reproduction performance, welfare, and health of animals [18,19]. In general, cold stress is common in weaning pigs, while the effects of heat stress are more of a concern in finishing pigs. Therefore, a major proportion of the total cost involved in pig farming is spent on maintaining the optimum temperature for pigs [20]. Similarly to our study, various experiments conducted in other countries have also reported the cooling and heating efficiencies of GHPs in broiler houses and swine farms $[4,15,21]$. In the current study, the decrease in temperature in the GHP-installed house might be because of the efficient degree change per unit of energy consumption of the GHP system [9]. Additionally, a direct heat exchange system in a single-loop configuration increases the efficiency of the GHP system [22], which can efficiently increase or decrease the temperature of the pig house depending on the season. THI is considered as a basis for the safety index to explain the categories of heat stress in animals. Myer and Bucklin [19] reported that humidity is not harmful for swine unless a high temperature is combined with a high humidity. According to the National Atmospheric and Oceanic Administration [23], THI $\geq 84$ is classified as an emergency, $\mathrm{THI} \leq 74$ is safe, and $74<\mathrm{THI}<79$ is considered as an alert for animal welfare. In the present study, the THI of the GHP-connected pig house fell within the safety zone for all of the phases of growth.

The COP is measured by dividing the heat output $(\mathrm{kWh})$ by the electrical input $(\mathrm{kWh})$, and it indicates the performance of the cooling system. The calculated COP-day average in this study was 4.36 , with the COP ranging from 4.10 to 4.50 . The calculated COP of the GHP cooling system was the same as the COP of 4.38 observed by Chokchai et al. [9] for a GHP cooling system. On average, the COP of a ground-source GHP lies within the range 
of 4.19 to 4.57 in cold weather and 3.9 to 4.53 in the summer season [24]. The results of the present study also fall within the optimum parameters, indicating the performance index and efficiency of the GHP cooling system. Aikins et al. [25] also reported that waterwater-type GHP systems are popular in Korea because of their ability to heat and cool, and their better COP values. The decreased water outflow temperature from the heat pump demonstrates the efficiency of the GHP cooling system [15] in maintaining the optimum temperature of the swine house.

In the present study, the reduction in the concentration of noxious gases is in agreement with the studies of Choi et al. [21] and Mun et al. [15], in which the cooling and heating effects of the GHP decreased the concentration of particulate matter and ammonia inside the swine house. This is because GHPs can provide fresh air continuously, which dilutes the harmful gases and improves the air quality [7]. $\mathrm{NH}_{3}$ and $\mathrm{H}_{2} \mathrm{~S}$ gases are harmful to animal health and also have harmful effects on the health of farmers and the environment [26]. Generally, the concentration of $\mathrm{H}_{2} \mathrm{~S}$ is less than $2 \mathrm{ppm}$, and the $\mathrm{NH}_{3}$ concentration is in the range of 0 to 40 ppm on swine farms [27]. Similarly, $\mathrm{PM}_{2.5}$ and the release of formaldehyde have harmful effects on the respiratory systems of humans and animals, and have a detrimental impact on the environment [28]. Particulate matter includes airborne particles with an aerodynamic diameter of $2.5 \mu \mathrm{m}$ or less. $\mathrm{PM}_{2.5}$ has become a threat to public health in South Korea, and can damage the lungs and penetrate the blood-brain and placental barriers. Formaldehyde is classified as a carcinogenic compound, and can cause irritation to the skin and eyes. No significant differences were observed in the concentration of $\mathrm{PM}_{2.5}$ and formaldehyde (except in the early finishing period in the case of $\mathrm{PM}_{2.5}$ ), and the values of $\mathrm{PM}_{2.5}$ and formaldehyde were in line with ambient air quality standards (AQS) in South Korea. The AQS safety range of $\mathrm{PM}_{2.5}$ is $50 \mu \mathrm{g} / \mathrm{m}^{3}$, and formaldehyde has no harmful effects at concentrations of $0.10-0.11 \mathrm{ppm}[29,30]$. Geothermal energy is popular worldwide as an environmentally friendly and renewable energy source that has a significant impact on the reduction of global climate change, protects public and animal health, and enhances energy security [31]. While conducting several experiments $[4,14,26]$ using GHP cooling and heating systems in poultry and swine houses, different scientists have reported the beneficial effects of the economically effective GHP cooling and heating system on the environment.

The important economic drivers for pig farmers are market weight and FCR [32], which cannot be ignored while introducing any of the latest innovations and technologies. In this study, the final BWG at the end of the experiment was significantly increased in the GHP-installed pig house. This might be due to the weight gain in the finishing period because the GHP cooling system maintained the internal temperature of the pig house within the thermoneutral zone. It has also been reported that heat stress negatively affects growth performance by decreasing FI, which eventually decreases the weight of pigs [33]. Therefore, a GHP cooling system can be installed in pig houses to reduce heat stress whilst having a positive impact on the growth performance parameters.

\section{Conclusions}

The implementation of a GHP cooling system in pig farms can improve the housing environment and growth performance parameters. Furthermore, GHPs are an environmentally friendly, renewable energy resource that can reduce the emission of noxious gases. Because of the high installation cost at animal farms, government assistance through subsidies is necessary for farmers to protect the environment and save energy. Further studies are recommended at commercial swine farms to evaluate the heating and cooling effects of the GHP system.

Author Contributions: Conceptualization, C.-D.K., H.-S.M., S.-R.L., K.-W.P., S.-B.R. and C.-J.Y; methodology, M.A.D., K.-W.P., D.R., H.-S.M., S.-R.L. and S.-B.R.; validation, M.A.D., H.-S.M. and C.-J.Y.; software, M.A.D., C.-D.K. and H.-S.M.; formal analysis, H.-S.M., D.R., M.A.D., S.-R.L. and K.-W.P.; investigation, M.A.D., H.-S.M., D.R., S.-R.L., K.-W.P., S.-B.R. and I.-B.C.; data curation, H.-S.M., M.A.D., D.R.; resources, S.-R.L., K.-W.P., S.-B.R. and C.-J.Y.; writing-original draft prepa- 
ration, H.-S.M., D.R. and M.A.D.; writing-editing and review, M.A.D., H.-S.M., I.-B.C., C.-D.K. and C.-J.Y.; visualization, M.A.D., H.-S.M., D.R.; supervision, C.-J.Y., H.-S.M., S.-B.R., S.-R.L., I.-B.C. and K.-W.P.; funding acquisition, C.-J.Y., H.-S.M. and K.-W.P.; project administration, S.-B.R.,S.-R.L., K.-W.P., C.-D.K. and C.-J.Y. All authors have read and agreed to the published version of the manuscript.

Funding: This research was supported by the Ministry of Trade, Industry and Energy, South Korea.

Institutional Review Board Statement: All of the experimental protocols and the rearing of the animals were in line with the guidelines of the Animal Care and Use Committee of Sunchon National University (SCNU IACUC 2020-09).

Informed Consent Statement: Not Applicable.

Data Availability Statement: Not Applicable.

Acknowledgments: We would like to acknowledge the Industrial Technology Innovation Business (20194210100020, Development and Demonstration of Renewable Energy Mixed-Use System for the Livestock Industry) for their support.

Conflicts of Interest: The authors have no conflict of interest to declare.

\section{References}

1. United Nations. World Population Prospects: The 2008 Revision; Highlights United Nations, Department of Economic and Social Affairs, Population Division: New York, NY, USA, 2009.

2. FAO World Livestock. Livestock in Food Security; FAO: Rome, Italy, 2011.

3. Krommweh, M.S.; Rösmann, P.; Büscher, W. Investigation of Heating and Cooling Potential of a Modular Housing System for Fattening Pigs with Integrated Geothermal Heat Exchanger. Biosyst. Eng. 2014, 121, 118-129. [CrossRef]

4. Islam, M.M.; Mun, H.-S.; Bostami, A.B.M.R.; Ahmed, S.T.; Park, K.-J.; Yang, C.-J. Evaluation of a Ground Source Geothermal Heat Pump to Save Energy and Reduce $\mathrm{CO}_{2}$ and Noxious Gas Emissions in a Pig House. Energy Build. 2016, 111, 446-454. [CrossRef]

5. Licharz, H.; Rösmann, P.; Krommweh, M.S.; Mostafa, E.; Büscher, W. Energy Efficiency of a Heat Pump System: Case Study in Two Pig Houses. Energies 2020, 13, 662. [CrossRef]

6. Costantino, A.; Fabrizio, E.; Ghiggini, A.; Bariani, M. Climate Control in Broiler Houses: A Thermal Model for the Calculation of the Energy Use and Indoor Environmental Conditions. Energy Build. 2018, 169, 110-126. [CrossRef]

7. Choi, H.C.; Salim, H.M.; Akter, N.; Na, J.C.; Kang, H.K.; Kim, M.J.; Kim, D.W.; Bang, H.T.; Chae, H.S.; Suh, O.S. Effect of Heating System Using a Geothermal Heat Pump on the Production Performance and Housing Environment of Broiler Chickens. Poult. Sci. 2012, 91, 275-281. [CrossRef]

8. Lund, R.; Ilic, D.D.; Trygg, L. Socioeconomic Potential for Introducing Large-Scale Heat Pumps in District Heating in Denmark. J. Clean. Prod. 2016, 139, 219-229. [CrossRef]

9. Chokchai, S.; Chotpantarat, S.; Takashima, I.; Uchida, Y.; Widiatmojo, A.; Yasukawa, K.; Charusiri, P. A Pilot Study on Geothermal Heat Pump (GHP) Use for Cooling Operations, and on GHP Site Selection in Tropical Regions Based on a Case Study in Thailand. Energies 2018, 11, 2356. [CrossRef]

10. Majuri, P. Ground Source Heat Pumps and Environmental Policy-The Finnish Practitioner's Point of View. J. Clean. Prod. 2016, 139, 740-749. [CrossRef]

11. Benli, H.; Durmuş, A. Evaluation of Ground-Source Heat Pump Combined Latent Heat Storage System Performance in Greenhouse Heating. Energy Build. 2009, 41, 220-228. [CrossRef]

12. Charoenvisal, K. Energy Performance and Economic Evaluations of the Geothermal Heat Pump System Used in the KnowledgeWorks I and II Buildings, Blacksburg, Virginia. Master's Thesis, Virginia Polytechnic Institute and State University, Blacksburg, VA, USA, 2008.

13. Lee, J.-Y. Current Status of Ground Source Heat Pumps in Korea. Renew. Sustain. Energy Rev. 2009, 13, 1560-1568. [CrossRef]

14. Choi, H.C.; Park, J.H.; Song, J.I.; Na, J.C.; Kim, M.J.; Bang, H.T.; Kang, H.J.; Park, S.B.; Chae, H.S.; Suh, O.S.; et al. Evaluation on Heating Effects of Geothermal Heat Pump System in Farrowing House. J. Anim. Environ. Sci. 2010, 16, $205-215$.

15. Mun, H.S.; Dilawar, M.A.; Jeong, M.G.; Rathnayake, D.; Won, J.S.; Park, K.W.; Lee, S.R.; Ryu, S.B.; Yang, C.J. Effect of a Heating System Using a Ground Source Geothermal Heat Pump on Production Performance, Energy-Saving and Housing Environment of Pigs. Animals 2020, 10, 2075. [CrossRef]

16. Adebiyi, O.A.; Muibi, M.A.; Alaba, O. Performance and Behavioural Characteristics of Pigs as Affected by Types and Duration of Evaporative Cooling. Niger. J. Anim. Sci. 2017, 2, 103-113.

17. Hessel, E.F.; Zurhake, C. Heating and cooling performance of an under floor earth tube air tempering system in a mechanical ventilated farrowing house. In Proceedings of the XVII World Congress of the International Commission of Agricultural and Bio Systems Engineering (CIGR), Québec, QC, Canada, 13-17 June 2010.

18. Li, S.; Ren, B.; Yang, H.; Yang, Y.; Ji, H.; Ni, J. Effect of Cold Stress with Different Intensities on HSP70 Expression in Wistar Rat Muscle, Spleen and Liver. Chin. J. Appl. Environ. Biol. 2006, 12, 235-238. 
19. Myer, R.; Bucklin, R. Influence of Hot-Humid Environment on Growth Performance and Reproduction of Swine. Document AN107, Extension, Institute of Food and Agricultural Sciences, 2001, University of Florida. Available online: http://edis.ifas.ufl. edu/an107 (accessed on 30 September 2021).

20. Riva, G.; Pedretti, E.F.; Fabbri, C. Utilization of a heat pump in pig breeding for energy saving and climate and ammonia control. J. Agric. Eng. Res. 2000, 77, 449-455. [CrossRef]

21. Choi, H.C.; Song, J.; Na, J.C.; Kim, M.J.; Bang, H.T.; Kang, H.G.; Park, S.B.; Chae, H.S.; Suh, O.S.; Yoo, Y.S.; et al. Evaluation on Cooling Effects of Geothermal Heat Pump System in Farrowing House. J. Anim. Environ. Sci. 2010, 16, 99-108.

22. Mustafa Omer, A. Ground-Source Heat Pumps Systems and Applications. Renew. Sustain. Energy Rev. 2008, 12, 344-371. [CrossRef]

23. National Oceanic and Atmospheric Administration (NOAA). Livestock Hot Weather Stress. Operations Manual Letter C-31-76; Department of Commerce, NOAA, National Weather Service Central Region: Kansas City, KA, USA, 1976.

24. Man, Y.; Yang, H.; Wang, J.; Fang, Z. In Situ Operation Performance Test of Ground Coupled Heat Pump System for Cooling and Heating Provision in Temperate Zone. Appl. Energy 2012, 97, 913-920. [CrossRef]

25. Aikins, K.A.; Choi, J.M. Current Status of the Performance of GSHP (Ground Source Heat Pump) Units in the Republic of Korea. Energy 2012, 47, 77-82. [CrossRef]

26. Dilawar, M.A.; Saturno, J.F.L.; Mun, H.-S.; Kim, D.-H.; Jeong, M.-G.; Yang, C.-J. Influence of Two Plant Extracts on Broiler Performance, Oxidative Stability of Meat and Odorous Gas Emissions from Excreta. Ann. Anim. Sci. 2019, 19, 1099-1113. [CrossRef]

27. Ni, J.-Q.; Heber, A.J.; Lim, T.-T. Ammonia and hydrogen sulfide in swine production. In Air Quality and Livestock Farming; CRC Press: Boca Raton, FL, USA, 2017; ISBN 978-1-315-73833-8.

28. Cambra-López, M.; Hermosilla, T.; Lai, H.T.L.; Aarnink, A.J.A.; Ogink, N.W.M. Particulate Matter Emitted from Poultry and Pig Houses: Source Identification and Quantification. Trans. ASABE 2011, 54, 629-642. [CrossRef]

29. Kang, D.; Kim, J.-E. Fine, Ultrafine, and Yellow Dust: Emerging Health Problems in Korea. J. Korean Med. Sci. 2014, 29 , 621-622. [CrossRef]

30. Subasi, N.T. Formaldehyde advantages and disadvantages: Usage Areas and Harmful E_ects on Human Beings. In Biochemical Toxicology-Heavy Materials and Nanomaterials; Ince, M., Kaplan Ince, O., Ondrasek, G., Eds.; IntechOpen: London, UK, 2020.

31. Pulat, E.; Coskun, S.; Unlu, K.; Yamankaradeniz, N. Experimental Study of Horizontal Ground Source Heat Pump Performance for Mild Climate in Turkey. Energy 2009, 34, 1284-1295. [CrossRef]

32. Kim, Y.S.; Kim, S.W.; Weaver, M.A.; Lee, C.Y. Increasing the Pig Market Weight: World Trends, Expected Consequences and Practical Considerations. Asian-Australas. J. Anim. Sci. 2005, 18, 590-600. [CrossRef]

33. Rauw, W.M.; Mayorga, E.J.; Lei, S.M.; Dekkers, J.C.M.; Patience, J.F.; Gabler, N.K.; Lonergan, S.M.; Baumgard, L.H. Effects of Diet and Genetics on Growth Performance of Pigs in Response to Repeated Exposure to Heat Stress. Front. Genet. $2017,8,155$. [CrossRef] 